\title{
Expression of Glucocorticoid Receptors in the Regenerating Human Skeletal Muscle
}

\author{
D. FILIPOVIĆ ${ }^{1}$, S. PIRKMAJER ${ }^{2}$, K. MIS ${ }^{2}$, T. MARS ${ }^{2}$, Z. GRUBIC ${ }^{2}$ \\ ${ }^{1}$ Laboratory of Molecular Biology and Endocrinology, Institute of Nuclear Sciences „Vinča“, \\ Belgrade, Serbia, ${ }^{2}$ Institute of Pathophysiology, Faculty of Medicine, University of Ljubljana, \\ Slovenia
}

Received January 4, 2011

Accepted February 16, 2011

On-line July 19, 2011

\section{Summary}

Many stress conditions are accompanied by skeletal muscle dysfunction and regeneration, which is essentially a recapitulation of the embryonic development. However, regeneration usually occurs under conditions of hypothalamus-pituitary-adrenal gland axis activation and therefore increased glucocorticoid (GC) levels. Glucocorticoid receptor (GR), the main determinant of cellular responsiveness to GCs, exists in two isoforms (GRa and GRß) in humans. While the role of GRa is well characterized, GR $\beta$ remains an elusive player in GC signalling. To elucidate basic characteristics of GC signalling in the regenerating human skeletal muscle we assessed GRa and GR $\beta$ expression pattern in cultured human myoblasts and myotubes and their response to 24-hour dexamethasone (DEX) treatment. There was no difference in GRa mRNA and protein expression or DEX-mediated GRa down-regulation in myoblasts and myotubes. GR $\beta$ mRNA level was very low in myoblasts and remained unaffected by differentiation and/or DEX. GR $\beta$ protein could not be detected. These results indicate that response to GCs is established very early during human skeletal muscle regeneration and that it remains practically unchanged before innervation is established. Very low GR $\beta$ mRNA expression and inability to detect GR $\beta$ protein suggests that GR $\beta$ is not a major player in the early stages of human skeletal muscle regeneration.

\section{Key words}

Myoblasts • Myotubes • Glucocorticoid receptors • Stress

\section{Corresponding author}

Sergej Pirkmajer, Laboratory for Molecular Neurobiology, Institute of Pathophysiology, Faculty of Medicine, University of Ljubljana, Zaloska 4, 1000 Ljubljana, Slovenia. Fax: + (386) 1 543 7021. E-mail: sergej.pirkmajer@mf.uni-lj.si

\section{Introduction}

Skeletal muscle is a prominent target for glucocorticoids (GCs) in health and disease. Although GCs constitute an essential part of systemic stress response, this often comes at the expense of the skeletal muscle. Chronically increased levels of (endogenous or exogenous) GCs can result in proteolysis, muscle wasting and overt myopathy, while shorter exposures to high GC concentrations in the intensive care setting have been implicated in the development of critical illness myopathy (Schweickert and Hall 2007, Menconi et al. 2007, Glass 2010). GCs may also adversely affect skeletal muscle during recovery from injury, which could be at least partly due to their antimyogenic effects in skeletal muscle precursors that participate in regeneration (Beiner et al. 1999, Almekinders et al. 1999, Ferrando 2000, Prelovšek et al. 2006, Dekelbab et al. 2007, Betters et al. 2008, Bruscoli et al. 2010). Perhaps paradoxically, GCs are currently the only effective pharmacological treatment for Duchenne muscular dystrophy, where degeneration-regeneration cycle is a prominent feature, and they were even reported to enhance differentiation in skeletal muscle precursors from mdx mice (Passaquin et al. 1993, Bushby et al. 2010, Bach et al. 2010, Matthews et al. 2010, Ciciliot and Schiaffino 2010).

Despite its importance, data on GC signalling during human skeletal muscle regeneration, which is characterized by satellite cell activation, myoblast proliferation, fusion into myotubes and later by (re)innervation and maturation into fully developed muscle fibers (Chargé and Rudnicki 2004, Ciciliot and 
Schiaffino 2010), remain incomplete. GC responsiveness of skeletal muscle precursors and adult fibers depends on the expression of the glucocorticoid receptor (GR), which has two splice variants (GR $\alpha$ and GR $\beta)$ in humans. Although the physiological role of the ligand-binding isoform GR $\alpha$ is very well established and characterized, the role of GR $\beta$, which does not bind GCs and probably acts as a dominant negative regulator of GR $\alpha$, remains elusive and its expression in skeletal muscle has not been unequivocally confirmed (Hollenberg et al. 1985, Bamberger et al. 1995, Bamberger et al. 1996, Oakley et al. 1996, De Castro et al. 1996, Oakley et al. 1997, Oakley et al. 1999, Pujols et al. 2002). Different levels of GR expression in myoblasts and myotubes could lead to their differential GC responsiveness with potentially important functional consequences. By exerting their effects primarily on myoblasts, which are actively proliferating cells, GCs could primarily affect the number of myogenic cells formed in response to injury and/or their fusion into myotubes. On the other hand, in case of greater responsiveness in the postmitotic myotubes, GCs could primarily disrupt protein synthesis and maturation into fully developed muscle fibers. In fact, myoblasts and myotubes were already reported to display differential responsiveness to tumour necrosis factor $\alpha$ and lipopolysaccharide (Prelovsek et al. 2006).

Our aim was therefore to assess GR $\alpha$ and GR $\beta$ mRNA and protein expression pattern in skeletal muscle precursors during regeneration and to evaluate how GCs affect their expression level. Tissue response to GCs depends also on 11ß-hydroxysteroid dehydrogenase type 1 and type 2, which under prevailing cellular conditions activate or inactivate, respectively, glucocorticoids (cortisol in humans and corticosterone in rodents) (Morton 2010). Type 1 11ß-hydroxysteroid dehydrogenase seems to play an important role in skeletal muscle, but skeletal muscle expression of type $211 \beta$ hydroxysteroid dehydrogenase, whose main role is to protect mineralocorticoid target tissues from GC action, has been subject to conflicting reports (Whorwood et al. 2002, Abdallah et al. 2005, Jang et al. 2007, Pirkmajer et al. 2010, Morton et al. 2010). In this study we focused on GRs since they are the main determinants of GC responsiveness (Burgeois and Newby 1979, Gehring et al. 1984).

Experiments were carried out on cultured human myoblasts and myotubes, which were treated for 24 hours with a synthetic GC dexamethasone (DEX). Human skeletal muscle culture is an established in vitro model of skeletal muscle regeneration, which can be used to study either early stages (myoblast proliferation and myotube formation) in aneural culture or later stages if nervemuscle co-culture is used (Askanas et al. 1987, Grubic et al. 1995, Mars et al. 2003, Prelovsek et al. 2006). The use of human tissue makes such studies even more relevant in clinical context, since characteristics of human and animal cultures differ in several important aspects (Askanas et al. 1987, Gajsek et al. 2008).

\section{Methods}

\section{Human skeletal muscle cell culture}

All the studies reported here were approved by the Ethical Commission at the Ministry of Health of the Republic of Slovenia (permit No: 63/01/99) muscle. Cultures were prepared as described in detail before (Askanas et al. 1987, Grubic et al. 1995, Mars et al. 2003, Prelovsek et al. 2006). Briefly, myoblast cultures were prepared from muscle tissue routinely discarded at orthopaedic operations from donors without neuromuscular disease. Muscle tissue was cleaned of connective and adipose tissue, cut to small pieces and trypsinised at $37^{\circ} \mathrm{C}$ to release muscle satellite cells. Isolated cells were grown in $100 \mathrm{~mm}$ Petri dishes (BD Falcon, Franklin Lakes, NJ) in growth medium (Advanced MEM supplemented with $10 \%$ (v/v) fetal bovine serum, $0.3 \%(\mathrm{v} / \mathrm{v})$ Fungizone, $0.15 \%(\mathrm{v} / \mathrm{v})$ Gentamicin (all obtained from Invitrogen, Paisley, UK)) at $37{ }^{\circ} \mathrm{C}$ in $5 \% \mathrm{CO}_{2}$-enriched air at saturation humidity. Myoblast colonies were selectively trypsinised just prior to fusion, transferred to $75 \mathrm{~cm}^{2}$ cell culture flasks and were grown for 2-3 more passages before they were transferred into 6-well plates and then either used for experiments or differentiated into myotubes. Myogenic differentiation was induced by switching subconfluent myoblast cultures from growth medium to differentiation medium (Advanced MEM supplemented with $2 \%$ fetal bovine serum). In a few days myoblasts started to fuse and polynuclear myotubes were formed. Myotubes were used for experiments after 3 weeks of differentiation. All experiments were carried out in polystyrene-treated 6well plates (BD Falcon).

\section{Dexamethasone treatment}

Dexamethasone-phosphate (DEX) (Krka, Novo Mesto, Slovenia) was used to avoid solubility problems of dexamethasone. Myoblasts and myotubes were incubated with either $0.2 \mu \mathrm{M}$ or $1 \mu \mathrm{M}$ DEX for 24 hours. 
Control cultures were grown in parallel with treated cultures and were harvested at the same time.

\section{Real-time PCR}

Total RNA was extracted using RNeasy Mini Kit (Qiagen, Hilden, Germany) and reverse transcribed with High Capacity cDNA Reverse Transcription Kit (Applied Biosystems). Real-time PCR was performed on ABI PRISM SDS 7500 (Applied Biosystems, Foster City, CA, USA), in 96-well format. GR $\alpha$ and GR $\beta$ mRNA were determined with gene expression assays based on TaqMan chemistry. Assay that was used to detect GR $\alpha$ contained $800 \quad \mathrm{nM}$ forward (5'-GAAGGAAACTCCAGCCAGAA-3') and reverse (5'-CAGCTAACATCTCGGGGAAT-3') primers and $200 \mathrm{nM}$ sense probe (6FAM-5'GCTTCCAAACATTTTTGGATAAGACCAT-3'-TAMRA) (Melo et al. 2004). Gene expression assay Hs00354508_m1 (Applied Biosystems) was used to detect GR $\beta$. Relative $(\Delta \Delta \mathrm{Ct})$ quantification method was employed to assess expression levels of target genes and $18 \mathrm{~S}$ rRNA (Applied Biosystems) was used as the endogenous control (see below).

\section{Endogenous controls for real-time PCR}

The ideal endogenous control should have a constant expression level regardless of experimental conditions. Although no such universal housekeeping gene exits, it is still extremely important to find the endogenous control that displays the lowest degree of variation in experimental system under consideration. We intended to study human skeletal muscle cells in two developmental stages (i.e. non-differentiated mononuclear myoblasts and differentiated myotubes) and their responses to DEX. Since myogenic differentiation and DEX both affect expression of many different housekeeping genes (Nishimura et al. 2008), it was therefore really vital to avoid artifacts due to changes in the endogenous control. We tested several commonly used endogenous controls (TaqMan Human Endogenous Control Plate, Applied Biosystems) and some of them showed profound differentiation-dependent or DEXdependent changes (data not shown). 18S rRNA was chosen out of 11 commonly used housekeeping genes (acidic ribosomal protein (huPO), beta-actin (huBA), b2-microglobulin (hub2m), cyclophilin (huCYC), glyceraldehyde-3-phosphate-dehydrogenase (huGAPDH), b-Glucuronidase (huGUS), hypoxanthine ribosyl transferase (huHPRT), phosphoglycerokinase (huPGK),
TATA binding protein (huTBP) and transferrin receptor (huTfR)) because it proved to be the most stable across all differentiation stages and treatments (data not shown).

\section{Western Blot analysis}

Cells were washed 2 times with ice-cold phosphate buffered saline and harvested in $200 \mu$ lysis buffer (20 mM Tris, $1 \mathrm{mM}$ EDTA, $10 \%$ (w/v) sucrose, $0.1 \%$ Triton X-100, and $1 \%(\mathrm{v} / \mathrm{v})$ Protease Inhibitor Cocktail (all obtained from Sigma), $\mathrm{pH}=7.4$ ). Insoluble components were removed by centrifugation $(12.000 \mathrm{x} \mathrm{g}$, 10 minutes, at $4{ }^{\circ} \mathrm{C}$ ). Protein content was determined by the Lowry protein assay (Sigma). Protein samples, prepared in Laemmli buffer, were separated in $10 \%$ NuPage Novex Bis-Tris Gel (Invitrogen) by using XCell SureLock electrophoresis system (Invitrogen) and transferred to PDVF membrane (Millipore, Billerica, MA). Membranes were blocked in blocking buffer $(0.2 \%$ (w/v) I-Block (Applied Biosystems), $0.3 \%$ (v/v) Tween 20 (Sigma) prepared in phosphate buffered saline). After an overnight incubation at $4{ }^{\circ} \mathrm{C}$ with appropriate primary antibodies membranes were incubated with alkaline phosphatase-conjugated secondary antibodies (Sigma). Blots were developed in $2 \%(\mathrm{v} / \mathrm{v})$ NBT/BCIP (Roche, Mannheim, Germany) solution prepared in developing buffer (0.1 M Tris, $\left.0.05 \mathrm{M} \mathrm{MgCl}_{2}, 0.1 \mathrm{M} \mathrm{NaCl}, \mathrm{pH} 9.5\right)$. Quantifications were performed with Chemi Genius BioImaging System (Syngen, Cambridge, UK) and actin was used as the loading control. We used the following primary antibodies: GR $\alpha$ (rabbit polyclonal antibody PA1-516, ABR-Affinity BioReagents Inc, Rockford, IL; diluted 1:200), GR $\beta$ (rabbit polyclonal antibody PA3-514, ABR-Affinity BioReagents Inc; diluted 1:200) and actin (rabbit polyclonal antibody SC-1616-R, Santa Cruz Biotechnology Inc., Santa Cruz, CA; diluted 1:1000). A representative Western Blot is shown below (Figure 1).

\section{Statistical analysis}

Two-way ANOVA, followed by Bonferroni's t-test, or Student t-test (as appropriate) was used to test for differences amongst groups. Results are expressed as means \pm SEM (standard error of the mean).

\section{Results}

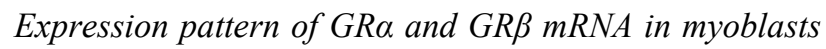
and myotubes

GR $\alpha$ and GR $\beta$ mRNA (Fig. 2) were expressed already at the level of non-differentiated mononuclear 


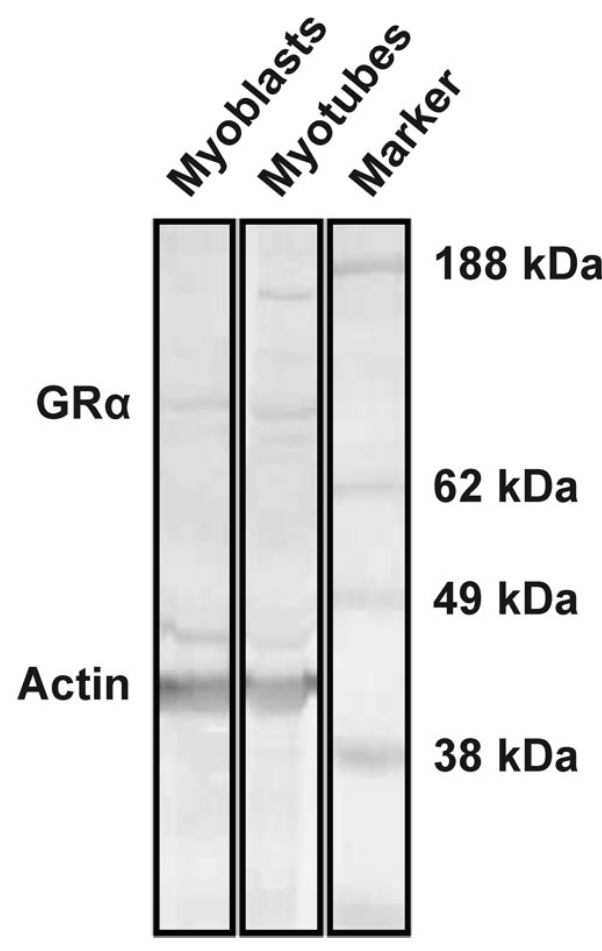

Fig. 1. GRa protein expression in human myoblasts and myotubes (Western Blot). A representative Western Blot from myoblasts (left column) and myotubes (middle column) grown in basal conditions is shown. Molecular weight marker (Marker) is shown on the right.

myoblast and differentiation into myotubes did not trigger any profound changes in their expression. There was a tendency towards an increase in GR $\alpha$ mRNA and a decrease in GR $\beta$ mRNA in myotubes compared to myoblasts, but these changes were not statistically significant $(\mathrm{p}=0.63$ and $\mathrm{p}=0.19$, respectively). GR $\beta$ mRNA level was 3 orders of magnitude lower than GR $\alpha$ mRNA $(\mathrm{p}<0.0001)$ and was close to the limit of reliable detection $\left(35-40^{\text {th }}\right.$ cycle). Two-way ANOVA did not show interaction between differentiation stage and GR isoform expression $(\mathrm{p}=0.67)$.

Effect of dexamethasone on GRa expression in human myoblasts and myotubes

After establishing that both GR isoforms are expressed in myoblasts and myotubes, we evaluated GR response to DEX treatment. Myoblasts and myotubes treated for 24 hours with $0.2 \mu \mathrm{M}$ or $1.0 \mu \mathrm{M}$ DEX downregulated GR $\alpha$ mRNA by $30-50 \%$ (Fig. 3). Response to 24-hour DEX treatment was not affected by the differentiation stage. Changes in GR $\alpha$ protein followed changes in GR $\alpha$ mRNA and GR $\alpha$ protein was reduced by 15-20\% compared to Basal. GR $\alpha$ protein level tended to

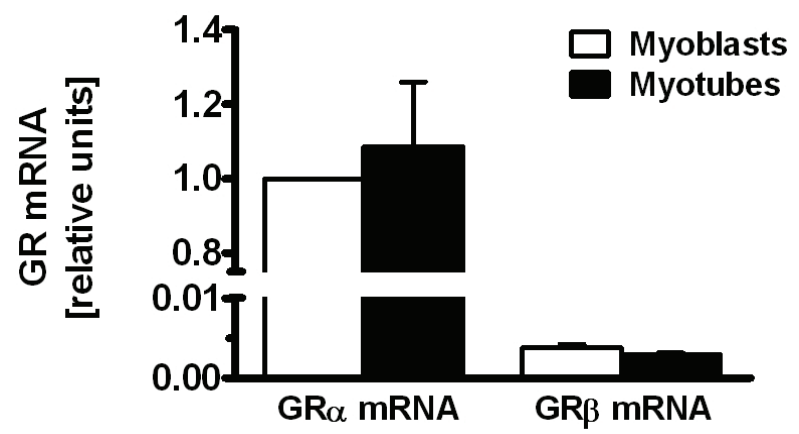

Fig. 2. GRa and GR $\beta$ mRNA expression in human myoblasts and myotubes (real-time PCR). GRa and GRB mRNA levels are reported in relative units, where GRa mRNA level in myoblasts was arbitrarily chosen as 1 . None of the differences in GR expression between myoblasts and myotubes was statistically significant. GR $\beta$ mRNA level was significantly lower in both differentiation stages (see text). 18S rRNA was used as the endogenous control. Columns are \pm SEM $(N=3-4)$.
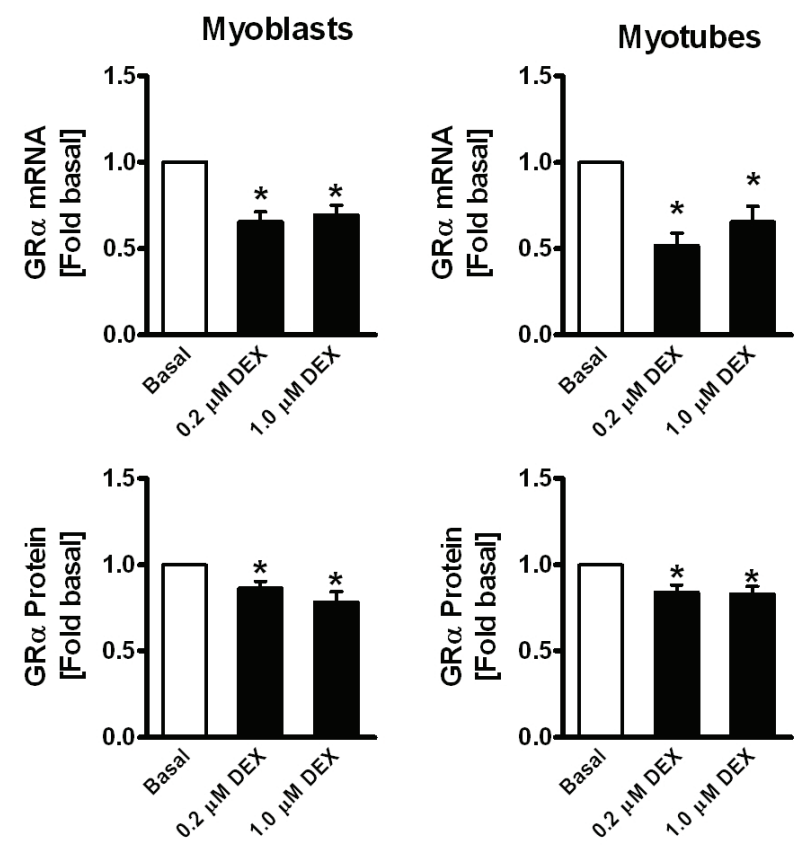

Fig. 3. GRa mRNA and protein expression in DEX-treated human myoblasts and myotubes. Top panels represent GRa mRNA level (real-time PCR) in myoblasts (left) and myotubes (right) after 24 hours of DEX treatment. Corresponding changes in GRa protein expression (Western Blot) are shown in the bottom panels. 18S rRNA was used as the real-time PCR endogenous control. Columns are means \pm SEM $(N=3-5), * p<0.05$ vs. Basal (t-test).

be lower in cells treated with $1.0 \mu \mathrm{M}$ DEX compared to $0.2 \mu \mathrm{M}$ DEX, but it did not reach the level of statistical significance.

Effect of dexamethasone on GR $\beta$ expression in human myoblasts and myotubes

GR $\beta$ mRNA was expressed at very low level in non-stimulated condition (Basal) and was not 

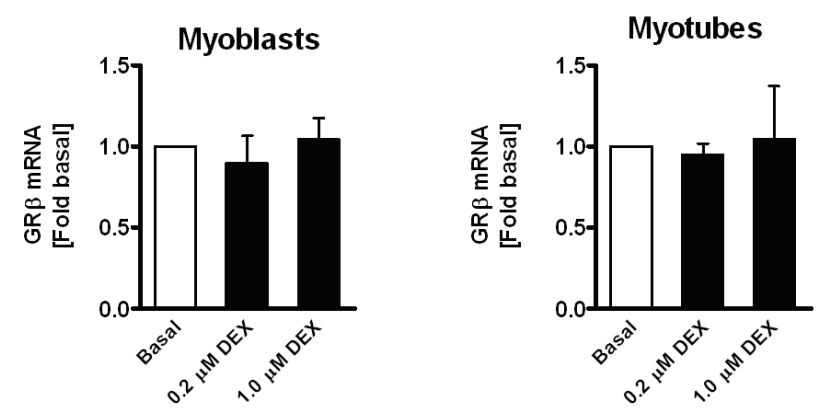

Fig. 4. GR $\beta$ mRNA expression in DEX-treated myoblasts and myotubes. GR $\beta$ mRNA level (real-time PCR) in myoblasts (left) and myotubes (right) after 24 hours of DEX treatment. 18S rRNA was used as the endogenous control. Columns are means \pm SEM $(\mathrm{N}=4)$. All the observed changes in GR $\beta$ level were statistically non-significant.

significantly affected neither by differentiation nor DEX treatment (Fig. 4). Interestingly there was a tendency towards a decrease in GR $\beta$ level in $0.2 \mu \mathrm{M}$ DEX treated myoblasts and especially myotubes (although it was not statistically significant). GR $\beta$ protein could not be reliably detected neither in myoblasts nor myotubes. Western Blot is therefore not shown.

\section{Discussion}

We demonstrated that GR $\alpha$ and GR $\beta$ mRNA are expressed in human myoblasts and myotubes. However, the GR $\beta$ mRNA level was at least 1000-times lower than the GR $\alpha$ mRNA and GR $\beta$ protein could not be detected. These results suggest that the predominant splicing pathway is the one leading to GR $\alpha$ mRNA, as has already been pointed out by Oakley et al. (1996). The alternative splicing event leading to GR $\beta$ mRNA is probably only a minor pathway during early skeletal muscle regeneration. Although GR $\beta$ was detected in skeletal muscle biopsies, our results are consistent with earlier studies, which showed either very low or no expression of GR $\beta$ in human skeletal muscle cultures (Whorwood et al. 2001, 2002, Pujols et al. 2002, De Bleecker et al. 2007). GR $\beta$ expression in skeletal muscle biopsies could in fact be mainly due to other cell types (i.e. not skeletal muscle fibers) (De Bleecker et al. 2007). However, methodological differences (Northern Blot vs. real-time PCR) could also explain failure to detect GR $\beta$ mRNA in some earlier papers. Like in our case, Pujols et al. (2002) were unable to detect GR $\beta$ protein although skeletal muscle expressed GR $\beta$ mRNA.

GR $\alpha$ and GR $\beta$ level was relatively constant in myoblasts and myotubes and induction of differentiation did not have a major impact on expression of either isoform. This observation does not support the notion of differential GC sensitivity in myoblasts and myotubes. Our result that GR level was independent of differentiation stage was similar to the result in paper by Sun et al. (2008) who did not see major changes in GR expression during $\mathrm{C} 2 \mathrm{C} 12$ myogenesis. In contrast, Aubry and Odermatt (2009) reported that C2C12 cells displayed a pronounced GR up-regulation during differentiation process.

24-hour DEX treatment down-regulated GR $\alpha$ mRNA with corresponding changes protein level. Although mRNA response was larger in relative terms, protein changes were entirely consistent. Moreover, kinetics of GR protein depends not only on the rate of transcription and translation but also on stability of the GR protein. These results are consistent with earlier reports from studies on human myoblasts (Whorwood et al. 2001) and L6 and C2C12 cells (Dekelbab et al. 2007, Menconi et al. 2008). Although changes in GR $\beta$ mRNA expression were rather challenging to quantify due to its very low level, we could not see any effect of differentiation or DEX treatment, which was consistent with our earlier observation that GR $\beta$ mRNA in human myoblasts had not responded to DEX and/or hypoxia (Pirkmajer et al. 2010). These results contrast with earlier reports that GC treatment could induce GR $\beta$ in human skeletal muscle cell culture (Whorwood et al. 2001).

Results presented in this paper and our previous results (Pirkmajer et al. 2010) have established that early precursors of human muscle regeneration already possess an elaborate molecular machinery to respond to GCs. Since no differences in GR $\alpha$ expression pattern or DEXmediated response could be observed in myoblasts and myotubes, this suggests that response to GCs at the receptor level is established very early and is not affected by myogenic differentiation program that takes place before the innervation of myotubes. Further studies are needed to evaluate the effect of innervation on GR $\alpha$ expression and function in skeletal muscle. Functional role of GR $\beta$ in the early stages of human skeletal muscle regeneration remains questionable due to its very low expression level and apparent lack of GR $\beta$ protein.

\section{Conflict of Interest}

There is no conflict of interest.

\section{Acknowledgements}

This study was supported by a grant to Prof. Zoran 
Grubic from the Slovenian Research Agency, and by short-term scholarship to Dragana Filipović from FEBS and Ad Futura Agency of Slovenia. Experiments were conducted in the Laboratory for Molecular Neurobiology,
Institute of Pathophysiology, Faculty of Medicine, University of Ljubljana, Slovenia. Technical assistance of Mrs Zvonka Frelih is gratefully acknowledged.

\section{References}

ABDALLAH BM, BECK-NIELSEN H, GASTER M: Increased expression of 11 beta-hydroxysteroid dehydrogenase type 1 in type 2 diabetic myotubes. Eur J Clin Invest 35: 627-634, 2005.

ALMEKINDERS LC: Anti-inflammatory treatment of muscular injuries in sport. An update of recent studies. Sports Med 28: 383-388, 1999.

ASKANAS V, KWAN H, ALVAREZ RB, ENGEL WK, KOBAYASHI T, MARTINUZZI A, HAWKINS EF: De novo neuromuscular junction formation on human muscle fibres cultured in monolayer and innervated by foetal rat spinal cord: ultrastructural and ultrastructural-cytochemical studies. J Neurocytol 16: 523-537, 1987.

AUBRY EM, ODERMATT A: Retinoic acid reduces glucocorticoid sensitivity in $\mathrm{C} 2 \mathrm{C} 12$ myotubes by decreasing 11beta-hydroxysteroid dehydrogenase type 1 and glucocorticoid receptor activities. Endocrinology 150: 27002708, 2009.

BACH JR, MARTINEZ D, SAULAT B: Duchenne muscular dystrophy: the effect of glucocorticoids on ventilator use and ambulation. Am J Phys Med Rehabil 89: 620-624, 2010.

BAMBERGER CM, BAMBERGER AM, DE CASTRO M, CHROUSOS GP: Glucocorticoid receptor beta, a potential endogenous inhibitor of glucocorticoid action in humans. J Clin Invest 95: 2435-2441, 1995.

BAMBERGER CM, SCHULTE HM, CHROUSOS GP: Molecular determinants of glucocorticoid receptor function and tissue sensitivity to glucocorticoids. Endocr Rev 17: 245-261, 1996.

BEINER JM, JOKL P, CHOLEWICKI J, PANJABI MM: The effect of anabolic steroids and corticosteroids on healing of muscle contusion injury. Am J Sports Med 27: 2-9, 1999.

BETTERS JL, LONG JH, HOWE KS, BRAITH RW, SOLTOW QA, LIRA VA, CRISWELL DS: Nitric oxide reverses prednisolone-induced inactivation of muscle satellite cells. Muscle Nerve 37: 203-209, 2008.

BOURGEOIS S, NEWBY RF: Correlation between glucocorticoid receptor and cytolytic response of murine lymphoid cell lines. Cancer Res 39: 4749-4751, 1979.

BRUSCOLI S, DONATO V, VELARDI E, DI SANTE M, MIGLIORATI G, DONATO R, RICCARDI C: Glucocorticoid-induced leucine zipper (GILZ) and long GILZ inhibit myogenic differentiation and mediate anti-myogenic effects of glucocorticoids. J Biol Chem 285: 10385-10396, 2010.

BUSHBY K, FINKEL R, BIRNKRANT DJ, CASE LE, CLEMENS PR, CRIPE L, KAUL A, KINNETT K, MCDONALD C, PANDYA S, POYSKY J, SHAPIRO F, TOMEZSKO J, CONSTANTIN C; DMD CARE CONSIDERATIONS WORKING GROUP: Diagnosis and management of Duchenne muscular dystrophy, part 1: diagnosis, and pharmacological and psychosocial management. Lancet Neurol 9: 77-93, 2010.

CHARGÉ SB, RUDNICKI MA: Cellular and molecular regulation of muscle regeneration. Physiol Rev 84: 209-238, 2004.

CICILIOT S, SCHIAFFINO S: Regeneration of mammalian skeletal muscle. Basic mechanisms and clinical implications. Curr Pharm Des 16: 906-914, 2010.

De BLEECKER JL, De PAEPE B, VERVAET VL, ARYS B, CREUS KK, WERBROUCK BF, MARTIN JJ: Distribution of glucocorticoid receptor alpha and beta subtypes in the idiopathic inflammatory myopathies. Neuromuscul Disord 17: 186-193, 2007.

DE CASTRO M, ELLIOT S, KINO T, BAMBERGER C, KARL M, WEBSTER E, CHROUSOS GP: The non-ligand binding $\beta$-isoform of the human glucocorticoid receptor (hGR $\beta$ ): tissue levels, mechanism of action, and potential physiologic role. Mol Med 2: 597-607, 1996.

DEKELBAB BH, WITCHEL SF, DEFRANCO DB: TNF-alpha and glucocorticoid receptor interaction in L6 muscle cells: a cooperative downregulation of myosin heavy chain. Steroids 72: 705-712, 2007. 
FERRANDO AA: Effects of inactivity and hormonal mediators on skeletal muscle during recovery from trauma. Curr Opin Clin Nutr Metab Care 3: 171-175, 2000.

GAJSEK N, JEVSEK M, MARS T, MIS K, PIRKMAJER S, BRECELJ J, GRUBIC Z: Synaptogenetic mechanisms controlling postsynaptic differentiation of the neuromuscular junction are nerve-dependent in human and nerve-independent in mouse C2C12 muscle cultures. Chem Biol Interact 175: 50-57, 2008.

GEHRING U, MUGELE K, ULRICH J: Cellular receptor levels and glucocorticoid responsiveness of lymphoma cells. Mol Cell Endocrinol 36: 107-113, 1984.

GLASS DJ: Signaling pathways perturbing muscle mass. Curr Opin Clin Nutr Metab Care 13: 225-229, 2010.

GRUBIC Z, KOMEL R, WALKER WF, MIRANDA AF: Myoblast fusion and innervation with rat motor nerve alter distribution of acetylcholinesterase and its mRNA in cultures of human muscle. Neuron 14: 317-327, 1995.

HOLLENBERG SM, WEINBERGER C, ONG ES, CERELLI G, ORO A, LEBO R, THOMPSON EB, ROSENFELD MG, EVANS RM: Primary structure and expression of a functional human glucocorticoid receptor cDNA. Nature 318: 635-641, 1985-1986.

JANG C, OBEYESEKERE VR, DILLEY RJ, KROZOWSKI Z, INDER WJ, ALFORD FP: Altered activity of 11 betahydroxysteroid dehydrogenase types 1 and 2 in skeletal muscle confers metabolic protection in subjects with type 2 diabetes. J Clin Endocrinol Metab 92: 3314-3320, 2007.

MARS T, KING MP, MIRANDA AF, WALKER WF, MIŠ K, GRUBIČ Z: Functional innervation of cultured human skeletal muscle proceeds by two modes with regard to agrin effects. Neuroscience 118: 87-97, 2003.

MATTHEWS DJ, JAMES KA, MILLER LA, PANDYA S, CAMPBELL KA, CIAFALONI E, MATHEWS KD, MILLER TM, CUNNIFF C, MEANEY FJ, DRUSCHEL CM, ROMITTI PA, FOX DJ; MD STARNET: Use of corticosteroids in a population-based cohort of boys with duchenne and becker muscular dystrophy. $J$ Child Neurol 25: 1319-1324, 2010.

MELO MR, FARIA CD, MELO KC, REBOUCAS NA, LONGUI CA: Real-time PCR quantitation of glucocorticoid receptor alpha isoform. BMC Mol Biol 5: 19, 2004.

MENCONI M, FAREED M, O'NEAL P, POYLIN V, WEI W, HASSELGREN PO: Role of glucocorticoids in the molecular regulation of muscle wasting. Crit Care Med 35: S602-S608, 2007.

MENCONI M, GONNELLA P, PETKOVA V, LECKER S, HASSELGREN PO: Dexamethasone and corticosterone induce similar, but not identical, muscle wasting responses in cultured L6 and $\mathrm{C} 2 \mathrm{C} 12$ myotubes. $J$ Cell Biochem 105: 353-364, 2008.

MORTON NM: Obesity and corticosteroids: 11beta-hydroxysteroid type 1 as a cause and therapeutic target in metabolic disease. Mol Cell Endocrinol 316: 154-164, 2010.

NISHIMURA M, NIKAWA T, KAWANO Y, NAKAYAMA M, IKEDA M: Effects of dimethyl sulfoxide and dexamethasone on mRNA expression of housekeeping genes in cultures of $\mathrm{C} 2 \mathrm{C} 12$ myotubes. Biochem Biophys Res Commun 367: 603-608, 2008.

OAKLEY RH, JEWELL CM, YUDT MR, BOFETIADO DM, CIDLOWSKI JA: The dominant negative activity of the human glucocorticoid receptor $\beta$ isoform. J Biol Chem 274: 27857-27866, 1999.

OAKLEY RH, SAR M, CIDLOWSKI JA: The human glucocorticoid receptor $\beta$ isoform: expression, biochemical properties and putative function. $J$ Biol Chem 271: 9550-9559, 1996.

OAKLEY RH, WEBSTER JC, SAR M, PARKER CR Jr, CIDLOWSKI JA: Expression and subcellular distribution of the beta-isoform of the human glucocorticoid receptor. Endocrinology 138: 5028-5238, 1997.

PASSAQUIN AC, METZINGER L, LÉGER JJ, WARTER JM, POINDRON P: Prednisolone enhances myogenesis and dystrophin-related protein in skeletal muscle cell cultures from mdx mouse. $J$ Neurosci Res 35: 363-372, 1993.

PIRKMAJER S, FILIPOVIC D, MARS T, MIS K, GRUBIC Z: HIF-1\{alpha\} response to hypoxia is functionally separated from the glucocorticoid stress response in the in vitro regenerating human skeletal muscle. $\mathrm{Am} J$ Physiol Regul Integr Comp Physiol 299: R1693-R1700, 2010.

PRELOVSEK O, MARS T, JEVSEK M, PODBREGAR M, GRUBIC Z: High dexamethasone concentration prevents stimulatory effects of TNF-alpha and LPS on IL-6 secretion from the precursors of human muscle regeneration. Am J Physiol Regul Integr Comp Physiol 291: R1651-R1656, 2006. 
PUJOLS L, MULLOL J, ROCA-FERRER J, TORREGO A, XAUBET A, CIDLOWSKI JA, PICADO C: Expression of glucocorticoid receptor alpha- and beta-isoforms in human cells and tissues. Am J Physiol Cell Physiol 283: C1324-C1331, 2002.

SCHWEICKERT WD, HALL J: ICU-acquired weakness. Chest 131: 1541-1549, 2007.

SUN L, TRAUSCH-AZAR JS, MUGLIA LJ, SCHWARTZ AL: Glucocorticoids differentially regulate degradation of MyoD and Id 1 by N-terminal ubiquitination to promote muscle protein catabolism. Proc Natl Acad Sci U S A 105: 3339-3344, 2008.

WHORWOOD CB, DONOVAN SJ, FLANAGAN D, PHILLIPS DI, BYRNE CD: Increased glucocorticoid receptor expression in human skeletal muscle cells may contribute to the pathogenesis of the metabolic syndrome. Diabetes 51: 1066-1075, 2002.

WHORWOOD CB, DONOVAN SJ, WOOD PJ, PHILLIPS DI: Regulation of glucocorticoid receptor alpha and beta isoforms and type I 11beta-hydroxysteroid dehydrogenase expression in human skeletal muscle cells: a key role in the pathogenesis of insulin resistance? J Clin Endocrinol Metab 86: 2296-2308, 2001. 